\title{
Partial lateral corpectomy associated with pediculectomy to treat extradural chondroma in a dog: technique description
}

\author{
[Corpectomia lateral parcial associada à pediculectomia no tratamento de condroma \\ extradural em um cão: descrição da técnica] \\ P.V.T. Marinho ${ }^{1}$, C.C. Zani ${ }^{1}$, P.C. Jark ${ }^{2}$, B.W. Minto ${ }^{2}$, M.T. Costa ${ }^{2}$ \\ ${ }^{1}$ Universidade Estadual de Londrina - UEL- Londrina, PR \\ ${ }^{2}$ Faculdade de Ciências Agrárias e Veterinárias - Unesp - Jaboticabal, SP
}

\begin{abstract}
This study aimed to describe in detail the surgical technique of partial lateral corpectomy (PLC) associated with pediculectomy to treat an in vitro extradural chondroma. A 12-year old female Cocker Spaniel was seen in the hospital with proprioceptive ataxia of hind limbs associated with extradural compression between the 1st and 2nd lumbar vertebrae. The owner opted for euthanasia since the patient's condition changed due to simultaneous illnesses that culminated in a poor prognosis. The patient's body was formally ceded to perform experimental spinal decompression. The technique was effective to completely remove the epidural mass with minimal manipulation of the spinal cord.
\end{abstract}

Keywords: dog, cord compression, extradural spinal tumors, neurosurgery

\section{RESUMO}

Objetivou-se descrever detalhadamente a técnica cirúrgica de corpectomia lateral parcial associada à pediculectomia no tratamento de um condroma extradural in vitro. Uma cadela de 12 anos de idade, raça Cocker Spaniel, foi atendida com ataxia proprioceptiva dos membros pélvicos associada à compressão extradural entre a primeira e a segunda vértebras lombares. Devido a alterações secundárias decorrentes de afecções concomitantes que culminavam em um prognóstico desfavorável, o proprietário optou pela eutanásia do paciente, e o cadáver foi formalmente cedido para realização de descompressão medular experimental. A técnica utilizada foi eficaz na remoção completa da massa extradural, com mínima manipulação da medula espinhal.

Palavras-chave: cão, compressão medular, neoplasias extradurais, neurocirurgia

\section{INTRODUCTION}

Neoplasms of the nervous system can affect the brain, spinal cord and peripheral nerves. Neoplasms involving the spinal canal are important causes of spinal pain and neurological locomotor signs in dogs (Da Costa, 2008).

Anatomically spinal neoplasms can be classified as extradural, intradural-extramedullary and intramedullary (Da Costa, 2008). Regarding their origin, they are classified as primary, when they develop from parenchyma of the spinal cord or in the associated meningeal/ependymal tissue; or secondary, when they include vertebral neoplasms that invade locally the medullary canal and metastases in the extradural space or marrow parenchyma (Dewey, 2008; Bagley, 2010). The clinical symptoms of such tumors are represented by spinal cord compression and/or impingement, as well as the development of edema, inflammation and peri-neoplastic hemorrhage (Dewey, 2008).

The treatment of dogs and cats with spinal neoplasms can be classified as supportive or permanent. The first is intended for the treatment of the sequelae of spinal tumors (e.g. spinal cord

Recebido em 21 de agosto de 2013

Aceito em 10 de julho de 2014

E-mail: paulo.veter@gmail.com 
edema, pain), while the definitive treatment is intended to eliminate neoplastic tissues (Dewey, 2008). Surgical treatment goals include tumor exposure, wide resection or biopsy, decompression of the spinal cord and nerve root and, occasionally, spinal stabilization (Bagley, 2010).

Generally, the vertebral, medullary or radicular thoracolumbar tumors are addressed through dorsal laminectomy or hemilaminectomy. Moreover, wide facetectomy and foraminotomy are required for proper exposure of large extradural tumors (Dewey, 2008). According to Bagley (2010), traditional techniques are unable to allow adequate access for complete removal of extradural tumors with surgical margins, as well as prevent further damage to the spinal cord during manipulation. Chauvet et al. (1999) state that incomplete removal of the tumor limits the outcome of surgery and euthanasia is the solution for most cases due to the fact that very few forms of treatment are described in the literature to treat this condition.

Rocha et al. (2012) reported excellent results for partial lateral corpectomy associated with pediculectomy (PPLC) performed as a therapy for chronic intervertebral disk disease in dogs; however, PPLC is not reported in the medical literature as a veterinary surgical technique to treat spinal cord compression secondary to neoplasms. This report describes the PPLC surgical technique performed on a dog corpse that was euthanized due to thoracolumbar extradural chondroma and an extra-skeletal chondroblastic osteosarcoma in subcutaneous tissue.

\section{CASE DESCRIPTION}

A 12-year-old female Cocker Spaniel dog with a history of breast cancer that had been removed about four months earlier was seen due to the presence of an axillary mass and proprioceptive ataxia of hind limbs, with about three months of evolution. The owner reported that the animal presented progressive weight loss, decreased activity level and appetite loss. Upon clinical examination, the patient showed emaciation, discreetly pale mucous and presence of a firm non-ulcerated mass attached in the axillary region of approximately $11 \times 9 \times 5.5 \mathrm{~cm}$. Furthermore, upon neurological examination the patient presented proprioceptive ataxia of hind limbs with preserved superficial pain, proprioceptive deficits, normal flexor (medial and lateral) and patellar reflexes in these members. Neurological examination result of forelimbs was normal. The cutaneous trunci reflex was diminished up to the 3rd lumbar vertebra.

The animal was anesthetized to perform incisional biopsy of the axillary masses and subjected to myelography $(0.5 \mathrm{ml} / \mathrm{kg}$ of Iohexol $)$ by puncturing the cisterna magna. The main clinical suspicion was metastasis of the breast or axillary tumor present in the thoraco-lumbar region. Radiographs taken in the latero-lateral (LL) and ventrodorsal (VD) projections after 5 and 15 minutes, following the contrast path along the spine, showed contrast blockage between the 1 st and 2nd lumbar vertebrae (Figure 1). The result of the histopathological examination of the axillary mass was suggestive of an extra-skeletal chondroblastic osteosarcoma in subcutaneous tissue.

The owner opted for euthanizing the patient due to secondary alterations resulting from concomitant conditions that culminated in a poor prognosis. The owner formally authorized the spinal decompression surgery using the technique of partial lateral corpectomy associated with pediculectomy.

The body was shaved, positioned in lateral recumbency tilted approximately $40^{\circ}$ to the table and rigidly attached with the left side facing up. We proceeded with the surgical approach of thoracolumbar spine starting up with a left dorsal paramedian incision (approximately $2.5 \mathrm{~cm}$ parallel to the spinous process) extending from the twelfth thoracic vertebra (T12) to the fourth lumbar vertebra (L4). Metzembaum scissors were used to incise the skin and lumbodorsal fascia. Following the incision of the lumbodorsal fascia and lateral epaxial muscles, divulsion was performed with blunt fingers for palpation and identification of vertebrae, with a clear view of the transverse processes and heads of the ribs. The musculature was diverted using Gelpi autostatic retractors and separated with Freer retractors for better exposure of the lateral region of the spine. After the surgical approach of the vertebrae involved in the compression, the lateral face of the fibrous ring and lateral aspects of the adjacent vertebral bodies were identified. 


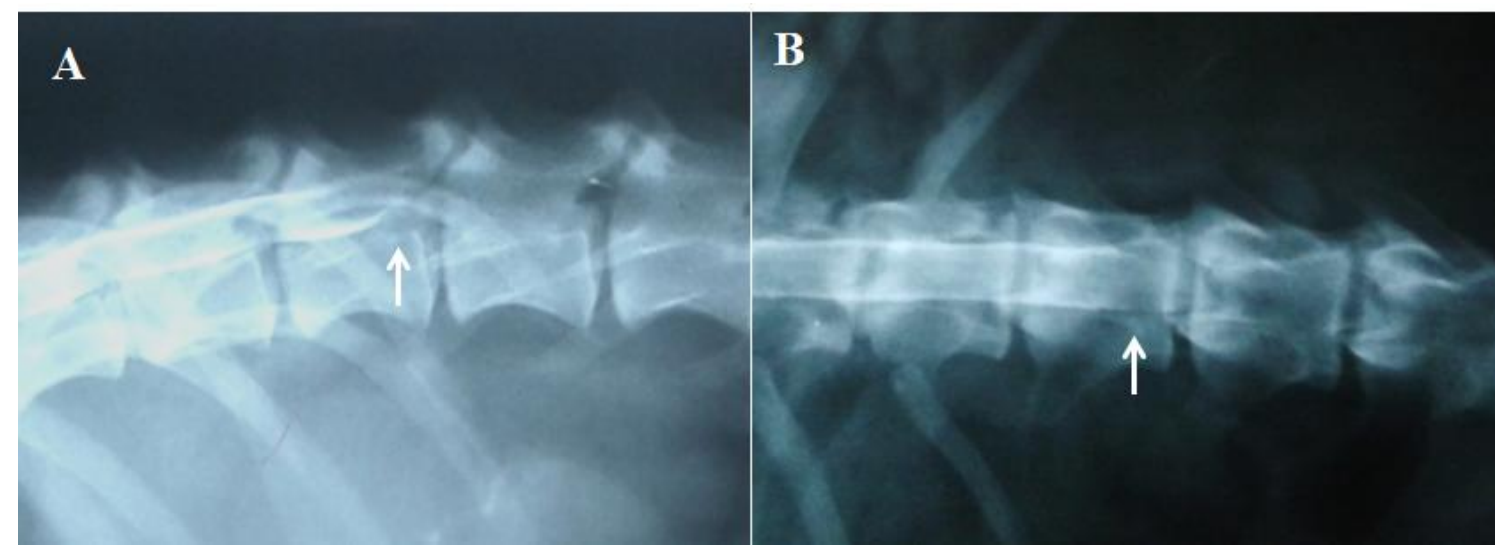

Figure 1. Dog. Myelography image of the thoracolumbar spine showing dorsal and ventral contrast blockage in the intervertebral space between L1-L2. (A) latero-lateral projection showing ventral spinal cord compression (arrow). (B) ventrodorsal projection showing symmetrical ventrolateral compression (arrow).

The partial lateral corpectomy (PLC) was divided into two phases. The first phase consisted of previously marking the drilling with a scalpel. Vertebral body milling began with the high speed electric drill placed perpendicularly to the frontal axis of the spine (vertical plane for a dog positioned in lateral recumbency), above the chosen ventral margin, previously marked, and extended to the floor of the spinal canal. The cutter initially penetrated the lateral cortical bone of the vertebral body, and then the beginning of the spongy bone.

When the previously set limits were achieved (Figure 2A), the drilling stopped and we proceeded to perform the pediculectomy. The initial drilling in the place of the corpectomy allowed a good fit of the drill, minimizing the risk of sliding into the spinal canal during the second phase of the milling of the vertebral body.

To perform the pediculectomy, the accessory process of the cranial vertebra to the affected intervertebral space was removed, using a Ruskin gouge to create a "window" with the high speed electric drill in the region below the joint facet, around the intervertebral foramen, preserving the articular processes, until the inner cortex and the periosteum were reached (Figure 2B). The periosteum was removed using Kerrison tweezers, thus allowing the cord and the floor of the spinal canal to be inspected. Following the pediculectomy and using the floor of the vertebral canal as reference to guide the angle of drilling in the vertebral body, the corpectomy was performed (the second phase of PLC) according to the guiding marks.

The bone was previously protected using two Freer retractors (Figure 2C) in order to prevent any iatrogenic injury during milling. The slot, centered on the intervertebral space, was dimensioned according to Moissonier et al. (2004) as follows: $1 / 4$ caudal vertebral body length for the caudal margin, $1 / 4$ cranial vertebral body length for the cranial margin, $1 / 2$ to $2 / 3$ vertebral body width for the depth margin and $1 / 2$ vertebral body height for the ventral margin.

Throughout the drilling, the drill was perpendicular to the tilting table (approximately $40^{\circ}$ ), and the previously exposed floor of the spinal canal was the main reference point guiding the milling. A small diameter disk was used towards the end of the drilling up to the point that the remaining cortical bone of the vertebral body seemed fragile. Drilling stopped when the dorsal longitudinal ligament was reached, so this ligament was between the instrument and the vertebral sinus, thus avoiding sinus bleeding and preventing iatrogenic injury to the spinal cord. When the cortical bone was thin enough, it was removed along with the dorsal longitudinal ligaments and remains of the annulus fibrosus using gouge forceps until the ventral portion of the spinal canal could be observed (Figure 2D). 
The prominent ventral mass (Figure 3A) was completely removed using a dental spatula and gouge. Decompression was completed when the spinal cord could be seen throughout the slot length without being lifted off the floor of the spinal canal (Figure 3B) and when blind palpation using a dental explorer on the other side of the spinal canal found no resistance. The collected material was preserved in $10 \%$ formalin and sent for histopathological analysis. The histopathological evaluation showed fragments of mature cartilaginous tissue along fibrous stroma, with typical chondrocytes forming cysts interspersed with basophilic chondroid material and grouped spindle cells with low pleomorphism, featuring a chondroma in the medullary canal.

\section{DISCUSSION}

Extradural tumors in dogs can be either primary or secondary to the invasion of vertebral tumor or metastases from other tumors that eventually can affect the spinal canal. The primary vertebral tumors that can invade the spinal canal are osteosarcoma, chondrosarcoma, multiple myeloma, fibrosarcomas and hemangiosarcomas (Mcentee and Dewey, 2013). Besides the vertebral tumors, metastases from breast and prostate carcinomas may also affect the extradural space. The patient had a breast tumor removed previously, but no data regarding the histological type. Since mammary carcinoma is the most frequent histological type in bitches with mammary neoplasms, the hypothesis that spinal cord compression was caused by a metastasis of the mammary tumor was entertained, but the histopathological evaluation detected chondroma (Mcentee and Dewey, 2013). The neoplasms of cartilaginous origin located in the spinal cord as chondroma and chondrosarcoma may originate from the vertebral body, via spinous, transverse, pedicle, lamina process or from a metaplasia of the connective tissue adjacent to the spinal cord. However, they are rare in both human and veterinary medicine (Russo et al., 2010; Marinho et al., 2013).

Surgical removal by hemilaminectomy and dorsal laminectomy is considered the method of choice for the therapy of extradural neoplasms of the thoracolumbar region (Bagley, 2010). For this author, in the ventral compression, the surgical margin is compromised when using these traditional techniques and the complete removal of the neoplastic material from the spinal canal is not performed satisfactorily. The PPLC allowed effective spinal decompression with complete visualization of the dimensional limits of the mass, in addition to the removal of the floor of the spinal canal, the site where the tumor was attached.

According to Moissonnier et al. (2004), classical decompression techniques allow approaching the spinal canal either via dorsal or dorsolateral; however, visualization and removal of the material compressing the spinal cord involves substantial handling of the spinal cord during surgery and may contribute to iatrogenic injury thereof. The use of potential motors in humans showed that the spinal cord (already compromised by vascular and degenerative diseases) is highly sensitive to surgical manipulation (Kitagawa et al., 1989). The PPLC allowed approaching the ventral spinal canal and removing of epidural mass with minimal handling, thus avoiding unnecessary iatrogenic injury to the spinal cord. A recent study evaluated the biomechanical interference that corpectomy alone or combined with hemilaminectomy exerts on the spine. The results of the study suggest that PLC alone leads to some vertebral instability, but axial torsion and lateral shear were not affected by the procedure (Revés et al., 2011). According to the same author, when performed associated with hemilaminectomy, the spinal visualization can improve dramatically, but produces a significant increase in the stability of the column during flexion/extension, axial rotation, dorsal/ventral and lateral shear. Results reported by Rocha et al. (2012) and Marinho (2013) for the use of corpectomy associated with pediculectomy did not show clinical and/or radiographic instability. For these authors, this happened because the disc had not been completely removed/destroyed, since it plays an important role in the stability of the forces of flexion/extension, lateral bending and axial torsion. These results corroborate $\mathrm{Ng}$ et al. (2003) and further emphasize the important role played by the articular facets in resisting the ventral/dorsal shear and torsion forces. 


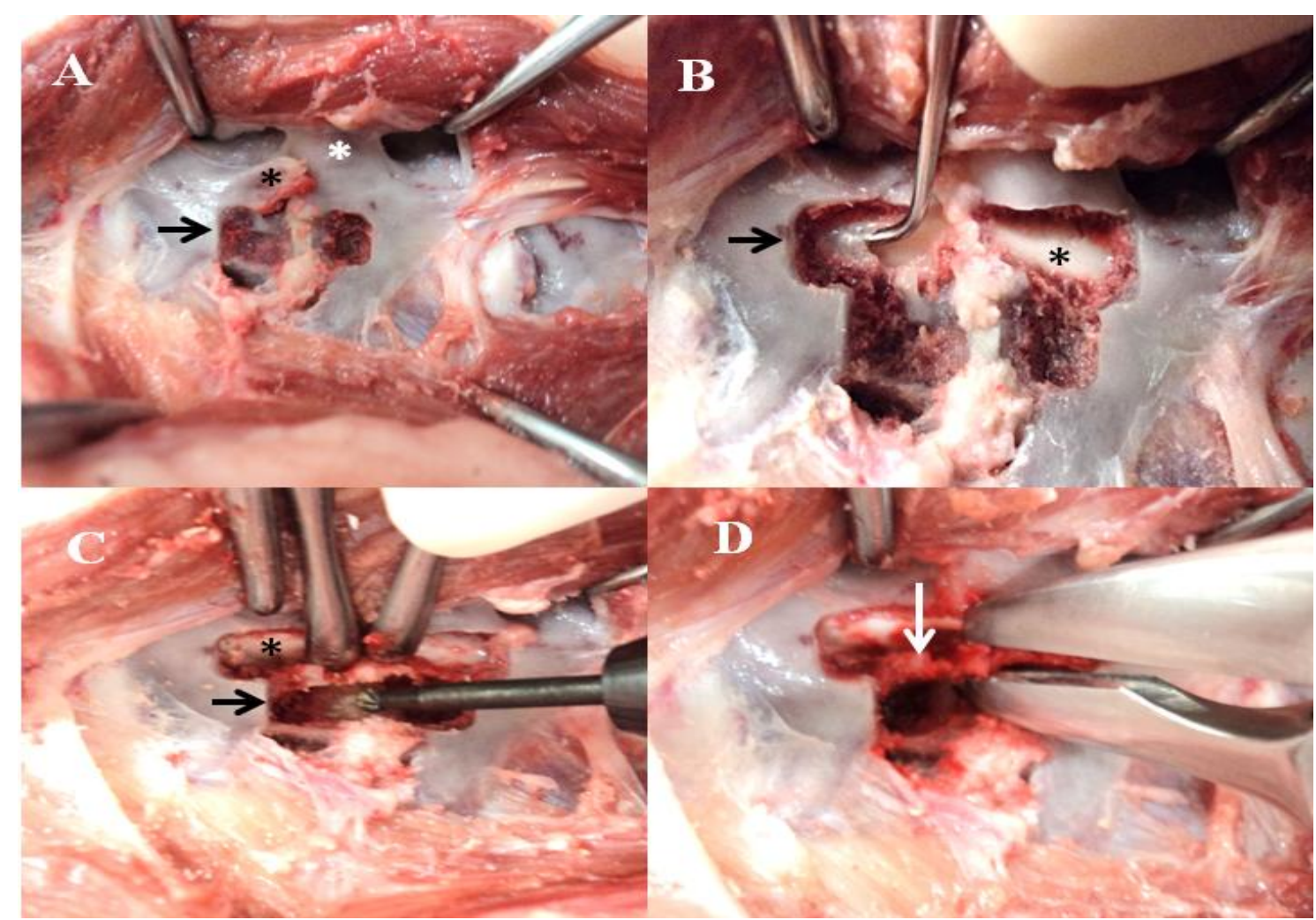

Figure 2. Corpse. Photographs showing the partial lateral corpectomy (PLC) associated with pediculectomy performed. (A) beginning of the corpectomy (arrow), accessory process (black asterisk) and articular facet (white asterisk); (B) first phase, pediculectomy (arrow) reaching the inner cortex and periosteum (asterisk); (C) second phase, corpectomy (arrow) and visualization of the spinal cord (asterisk); (D) removal of the cortical bone, dorsal longitudinal ligament and annulus fibrosus that stands between the pediculectomy and partial lateral corpectomy.

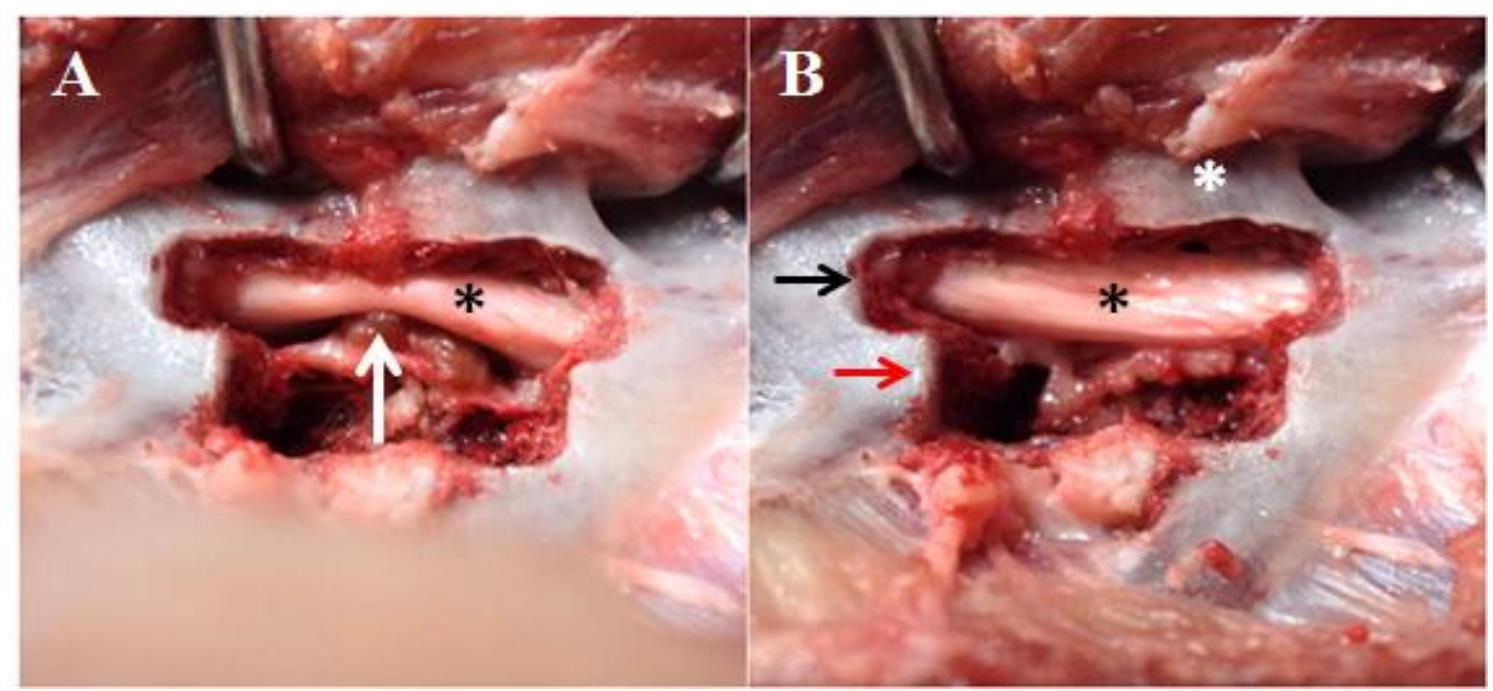

Figure 3. Corpse. Photographs showing severe ventral spinal cord compression (asterisk) by extradural mass (arrow) in the intervertebral space between L1 and L2. (A) partial lateral corpectomy (red arrow) associated with pediculectomy (black arrow) showing the spinal cord resting on the floor of the spinal canal (black star) after complete removal of the mass. (B) preserved articular facet (white asterisk). 


\section{CONCLUSIONS}

The results showed that the technique of partial lateral corpectomy associated with pediculectomy was effective to completely remove the extradural mass with minimal manipulation of the spinal cord.

\section{REFERENCES}

BAGLEY, R.S. Spinal Neoplasms in Small Animals. Vet. Clin. North Am. Small Anim. Pract., v.40, p.914-927, 2010.

CHAUVET, A.E.; HOGGE, G.S.; SANDIN, J.A. et al. Vertebrectomy, Bone Allograft Fusion, and Antitumor Vaccination for the Treatment of Vertebral Fibrosarcoma in a Dog. Vet. Surg., v.28, p.480-488, 1999.

DA COSTA, R.C. Neoplasias do sistema nervoso. In: DALECK, C.R.; DENARDI, A.B.; RODASKI, S. Oncologia em cães e gatos. São Paulo: Roca, 2008, p.411-435.

DEWEY, C.W. Myelopathies: Disorders of the Spinal Cord. In: __ A practical guide to canine and feline neurology. 2.ed. Iowa: WileyBlackwell, 2008. p.183-186.

KITAGAWA, H.; ITOH, T.; TAKANO, H. et al. Motor evoked potential monitoring during upper cervical spine surgery. Spine, v.14, p.1078-1083, 1989.

MARINHO, P.V.T. Corpectomia lateral parcial associada à pediculectomia no tratamento de discopatia toracolombar crônica em cães. 2013. 61f. Monografia (Monografia apresentada ao Programa de Aprimoramento Profissional, Área de Clínica Cirúrgica de Pequenos Animais, da Universidade Estadual Paulista "Júlio de Mesquita Filho", Jaboticabal, SP).
MARINHO, P.V.T.; JARK, P.C.; AVANTE, M.L. et al. Tratamento cirúrgico de condroma extradural lombar em cão - relato de caso. Semina, v.34, p.945-960. 2013.

McENTEE, M.C.; DEWEY, C.W. Tumors of the Nervous System. In: WITHROW S.J., MACEWEN E.G. Small animal Clinical Oncology, 5.ed. St Louis, Missouri: WB Saunders, 2013. p.583-596.

MOISSONNIER, P.; MEHEUST, P.; CAROZZO, C. Thoracolumbar lateral corpectomy for treatment of chronic disc herniation: technique description and use in 15 dogs. Vet. Surg., v.33, p.620-628, 2004.

NG, H.W.; TEO, E.C.; LEE, K.K. et al. Finite element analysis of cervical spinal instability under physiologic loading. J. Spinal Disord. Tech., v.16, p.55-65, 2003.

REVÉS, N.V.; BÜRKI, A.; FERGUSON, S. et al. Influence of partial lateral corpectomy with and without hemilaminectomy on canine thoracolumbar stability: a biomechanical study. Vet. Surg., v.00, p. 1-7, 2011.

ROCHA, A.G.; MORATO, G.O.; CHUNG, D.G. et al. Corpectomia lateral associada à pediculectomia para tratamento de discopatia toracolombar crônica em cães. Estudo de 27 casos. J. Brasil. Cienc. Anim. v.5, p.35, supl., 2012.

RUSSO, V.; PLATANIA, N.; GRAZINO, F.; ALBANESE, V. Cervical spine chondroma arising from C5 rigthhemilamina: a rare case of spinal cord compression. Case report and review of literature. J. Neurosurg. Sci., v.54, p.113-117, 2010 . 